\title{
Press panel recommends a unified budget for science
}

\begin{abstract}
Washington. The US government should change the way it adds up its investment in science and technology (S\&T), and prepare a specific S\&T budget proposal each year for consideration by Congress, according to a report published this week by the National Research Council (NRC).

The report was prepared for the Senate Appropriations committee by a panel chaired by Frank Press, former president of the National Academy of Sciences and, prior to that, sci-
\end{abstract} ence advisor to

President Jimmy Carter. It rejects the idea of a Department of Science, being backed by various Republicans in Congress, and suggests instead a stronger co-ordinat-

ing role for Press: rejects plan for the White House's Science Department. Office of Science and Technology Policy (OSTP).

The NRC proposes a new measure for science and technology spending designed to underpin a more tightly-integrated budget process. This 'metric' would exclude about $\$ 30$ billion which is currently spent on development and testing by the Department of Defense (DoD) and other agencies, leaving a total science and technology budget of roughly $\$ 38$ billion.

OSTP and the Office of Management and Budget (OMB) would, each year, lead a public process to set priorities within that budget, says the report. Congress would develop a way to examine the science and technology budget as a whole, it suggests, before it is split up and considered by individual appropriations subcommittees.

Senators asked for the report a year ago, when Tom Harkin (Democrat, Iowa), then chair of the Labor, Health and Human Services and Education appropriations subcommittee, wanted to know why there was no extra money for research at the National Institutes of Health (NIH), when the federal government was spending $\$ 70$ billion a year on R\&D (see Nature 372, 5; 1994).

At the time, Press said that he hoped the report could match the influence of Vannevar Bush's influential Science - The Endless Frontier which, in 1945, first established the principle of substantial US government support for science in peacetime.

But where Bush offered specifics including ambitious budget targets for his proposed National Research Foundation, which would emerge in 1950 as the National Science Foundation - the Press document avoids numbers. Instead, it offers proposals for reforming the vast science-funding structure that has developed since Bush's day.

Marcia McNutt, professor of geophysics at the Massachusetts Institute of Technology (MIT) and a member of the NRC panel, says that the proposed reforms would mean "a larger role for OSTP and for the president's science advisor". Press, when he occupied the latter post, is remembered for having established a close working relationship with OMB.

The new 'metric' proposed by the panel would remove systems development work worth $\$ 26$ billion at the Department of Defense (DoD), $\$ 3$ billion at the National Aeronautical and Space Administration (NASA) and \$1.3 billion at the Department of Energy (DoE), from the government's conventional calculation of the money it spends on science and technology. This would leave the $\$ 38$ billion that constitutes investment in new knowledge.

The panel recommends that in the latter area, the President should present an annual budget, "including areas of increased and reduced emphasis". It concedes that recent administrations have already taken steps in this direction, but argues that they have not gone far enough. "Right now, the science budget is put together completely after the fact," says McNutt.

The panel asks Congress to "create a process" that would enable the President's science budget to be considered as a single entity by both the budget committees and the full appropriations committees. The Congressional Budget Office would also be asked to track the progress of the science budget through the appropriations process.

In rejecting the idea of a Department of Science, as proposed by Congressman Robert Walker (Republican, Pennsylvania), the panel argues for a diversity of funding sources. It says the Walker plan would fail to co-ordinate science across government, because it excludes both DoD and NIH.

At the same time, the NRC panel voiced scepticism about some technology programmes being pursued by the Clinton administration. The panel says it doubts that the Advanced Technology Programme is the best way to use scarce federal $R \& D$ dollars, and suggests that funds for cooperative research and development agreements (CRADAs) could be better spent elsewhere.

This week, Press has been briefing administration and Congressional staff on the report. The administration is likely to welcome its emphasis on an enhanced role for OSTP. But it is the response of Congress that will determine whether it has any lasting impact.

Colin Macilwain

\section{Environment agency is urged to focus on strategic priorities}

Washington. The US Environmental Protection Agency's (EPA's) Office of Research and Development (ORD) last week released a draft strategic plan listing six high-priority topics for future research in the agency. The report recommends augmented programmes to study disinfectants in drinking water, airborne particulate matter, human health hazard assessment, ecosystem protection, endocrine disruptors and the use of new technology in pollution prevention.

According to Joseph Alexander, deputy chief of science at EPA, detailed research plans for each of these six areas should be ready by next summer. Some may receive additional funding in 1997, although fully developed research programmes are likely to wait until 1998 .

The strategic plan calls for EPA to "focus research and development on the greatest risks to people and the environment, taking into account their potential severity, magnitude and uncertainty". The draft report, submitted to both the agency's science advisory board and the National Research Council, is part of an broad effort by the environmental agency to improve the quality of its science.

EPA has also asked the National Academy of Sciences to propose environmental research priorities for the next decade. Alexander says that the panel for that study, which is still being selected, could begin work by January.

In a foreword to the report, Robert Huggett, chief of science at EPA, writes that the choice of risk-based decision making principles for setting research priorities will "transcend economic and political changes". But that may be wishful thinking. Several Congressional committees have tried this year to prohibit EPA from conducting research in specific areas, including global warming and indoor air pollution.

The bills containing these provisions have yet to pass, and it is not certain how binding the restrictions will be if they do. But Congress will certainly have a say in whatever research priorities EPA proposes. In fact, EPA's funding bill, which is being voted in by Congress this week, requires ORD to report to the Senate on how and where it intends to spend its extramural research dollars.

The broadly worded strategic plan sets a number of ambitious goals for EPA science. These include improving the science of risk assessment, and integrating human health research with ecosystem science. But that work will require manpower, and Huggett says he is disturbed by language accompanying the EPA funding bill implying that the agency will have to cut its work force in the years to come.

Tony Reichhardt 